\title{
Trends in the legal labour reform policy in the Kyrgyz Republic
}

\author{
Kubanychbek Sovetovich Ramankulov",Ulan Turdubekovich Andashev, and Gulnaz \\ Kachkyn kyzy \\ J. Balasagyn Kyrgyz National University, Faculty of Law, Civil, Labor and Environmental Law \\ Department, Bishkek, Kyrgyz Republic
}

\begin{abstract}
The article is concerned with the analysis of the transformations in the labour market taking place in the Kyrgyz Republic (KR), which cause a great resonance in society, but continue to remain unexplored in the legal literature. Consequently, the purpose of the article is to identify the general trend in the legal labour reform policy and to determine the main directions of legal policy to improve the mechanism of legal regulation of labor. In the article, the objectives of classifying the main periods of the implementation of labor reforms (begun in 2005) are solved, analysis and assessment of the means of implementing reforms in terms of their compliance with national and international labor standards are carried out based on dialectical and logical methods, as well as the use of the systemic method. The article reveals serious inconsistencies between the deregulation policy and prohibitions in the labour market with the ILO Conventions No. 81, 87, 150, 155, which were ratified by the Kyrgyz Republic (except for the ILO Convention No. 155). In particular, the negative consequences of the deregulation policy for the field of labor safety and protection were noted, especially in the context of the onset of the COVID-19 coronavirus. Based on the analysis of the problems of the labor regulation reform policy, it is concluded that it is necessary to develop a unified state program for the development of the labour market, containing a system of strategic priorities, conceptual ideas, goals and measures that determine the prospects for improving the labor legislation of the Kyrgyz Republic on the basis of intensifying the processes of monitoring labor legislation and the practice of its enforcement in the Kyrgyz Republic. The provisions and conclusions of this article are of practical importance for the executive authorities implementing state policy in the field of labor.
\end{abstract}

Keywords: transformations, deregulation, prohibitions, labor standards

\section{Introduction}

The policy for the implementation of the reforms in the field of labor regulation in the last decade and a half is characterized by the instability of the state approach to the administration of labor issues, there is a clear tendency towards state non-interference in entrepreneurial activity, associated with both budget savings and the idea of the need to provide maximum

\footnotetext{
${ }^{*}$ Corresponding author: ramaks65knu@mail.ru
} 
economic freedom to entrepreneurs through the rights of the working population. This concept in the legal policy of the labour market is being actively pursued by some executive authorities (most often by the Ministry of Economy of the Kyrgyz Republic) and is aimed at limiting state regulation in the labour market and significantly reducing the legal guarantees of workers. Despite the increased social significance of the issues of legal labour reform policy, they remain practically unexplored. Therefore, there is an urgent need to analyze the ongoing transformations from the standpoint of establishing the main legal means of reforming the world of work, in clear assessments of the state of legal policy in this area from the point of view of compliance with the labor legislation of the Kyrgyz Republic and international labor standards.

\section{Methods}

The work examines the main periods of implementation of reforms in the labor market, which predetermines the use of the dialectical method as the main one, since the ratio of opposing trends in the policy of reforming the labor regulation sphere (marginal liberalization and state participation in labor regulation), as well as logical and systemic methods in establishing legal the content of the means of reform in relation to national and international labor standards.

\section{$3 \quad$ Results}

In the legal sphere, including in the sphere of labor law, the concept of reform [1] has become quite widespread, although it remains insufficiently defined and is not unambiguously stipulated in the legal categorical apparatus. In the literature, the general context of the relationship of this concept with legal policy is determined by the fact that "legal reform is an integral component (form of manifestation or means) of state legal policy" [2]. At the same time, the changes in the content of legal regulation in the labor sphere also represent one of the types of legal reforms [3].

Moreover, an analysis of the legislative process of recent years and normative documents on labour reform policy [4-5], adopted with the active lobbying of a non-core agency for this sphere - the Ministry of Economy of the Kyrgyz Republic - made it possible to identify a general trend related to the fact that the reform in the field of regulation of labor and relations

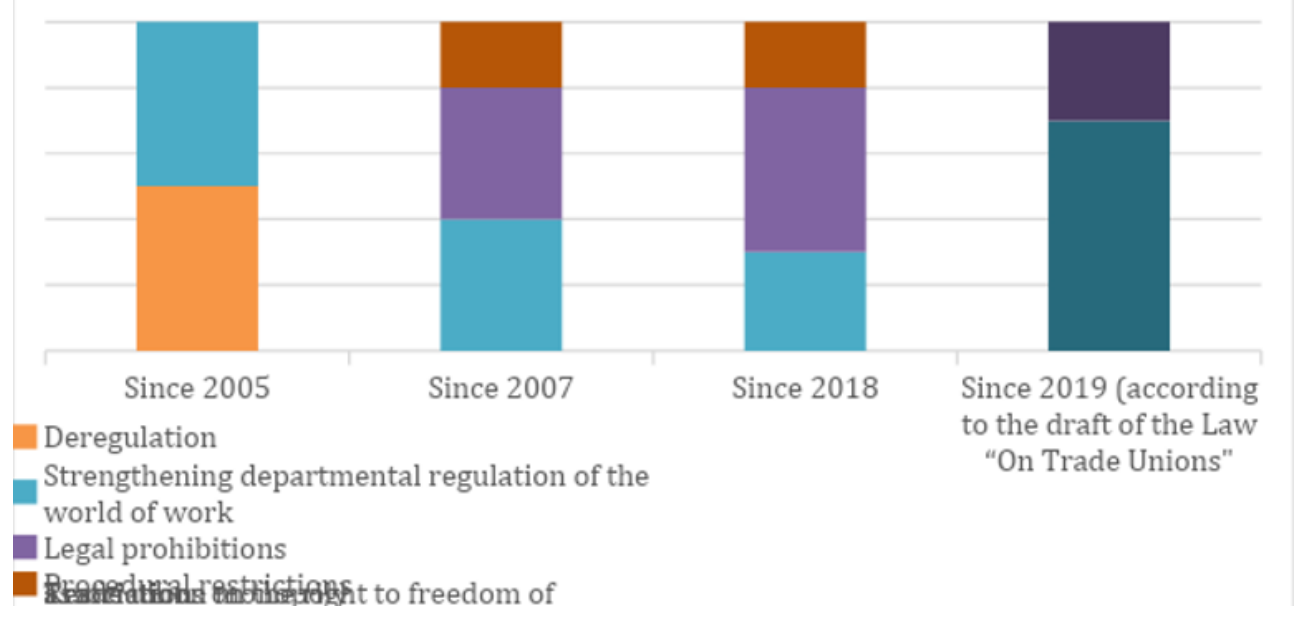

Fig. 1. Dynamics of legal means of labor reform policy. 
directly related to them is carried out by means and methods that are not adequate to the goals and objectives of labor legislation or focused on the deregulation of the world of work.

\section{Discussion}

Deregulation policy that has emerged since the early 2000s and then justified itself by the cancellation of outdated acts of the former USSR (see paragraph 3 of Article 36 of the Law of the Kyrgyz Republic of July 20, 2009, No. 241 "On regulatory legal acts of the Kyrgyz Republic"), has affected almost all spheres of public relations, including the sphere of labor and directly related relationship with them. The negative consequences of this policy were most noticeably manifested in relation to the regulation of labor protection. Consequently, the area of sanitary and epidemiological regulation by the time of the spread of coronavirus infection (COVID-19) in the territory of the Kyrgyz Republic has no legal regulation actually due to the abolition of the system of sanitary rules and norms in force in the Kyrgyz Republic on the basis of normative acts approved in the USSR (however, legal acts of the Kyrgyz Republic adopted in 2000 belong to the abolished sanitary norms and rules). This situation contributed to the actualization of the problem of establishing new rules governing labor relations outside of labor legislation [6], since the regulation of labor and directly related relations in Kyrgyzstan and Russia in the context of the COVID-19 pandemic has shifted to the sectoral (departmental) and local levels, including through acts of application of law. It should be noted that the deregulation policy excludes legal means from among the most effective tools to combat the spread of coronavirus infection COVID-19, does not allow effectively using international legal norms to counter this pandemic $[7,8]$.

A similar problem is observed in the system of occupational safety and health standards because a set of specific technical regulations in the field of labor protection (SNiP codes and regulations, SanPiN sanitary norms and rules and other standards) operated in the country on the basis of the regulations approved in the USSR. The current situation in the implementation of the deregulation policy in the field of labor protection does not comply with the norms (Part 1 of Article 4) of the ILO Convention No. 155 [9, 10], according to which the most representative organizations of employers and workers develop, implement and periodically revise an agreed national policy in the field of occupational safety, occupational health and the working environment.

The policy of dissemination of prohibitions and procedural restrictions in the labor market is associated with the adoption of the Law of the Kyrgyz Republic of May 25, 2007, No. 72 "On the procedure for conducting inspections of business entities", the implementation of which in the labor market is achieved through a variety of subordinate, mainly departmental (adopted by the Ministry of Economy of the Kyrgyz Republic) [11] regulations. These prohibitions and procedural restrictions apply to the scope of labor inspections and clearly contradict the requirements of the ILO Convention No. 81 [12], ratified by the Kyrgyz Republic, which establishes the right of the labor inspector to carry out any inspections without prior notice (Part 1 of Article 12). A kind of logical continuation of the policy of prohibitions in the labor sphere was the adoption by the Government of the Kyrgyz Republic of Resolution No. 586 of December 17, 2018 "On the introduction of a temporary ban (moratorium) on inspections of business entities", which introduced a temporary ban (moratorium) from January 1, 2019 to January 1, 2021 (extended and further) for inspections of business entities conducted by authorized bodies entitled to conduct inspections of business entities, including labor inspections. This prohibition also comes into clear conflict with international labor standards [13].

The attempts to establish a trade union monopoly are related to the draft of the new Law of the Kyrgyz Republic "On Trade Unions of the Kyrgyz Republic", which passed the second readings in the Jogorku Kenesh (Supreme Council) of the Kyrgyz Republic. Most of the 
norms of the above draft law on trade unions are based on the methods of legally imposed trade union monopoly, which clearly contradicts the principle of freedom of association stipulated by international labor standards [14] and the labor legislation of the Kyrgyz Republic. Moreover, as recent studies conducted by ILO experts show [15], trade union monopoly does not allow reforming the system of trade unions that is adequate to modern challenges in the context of globalization.

\section{Conclusion}

The study of the issues of the labour reform policy regulation makes it possible to note that the content of this policy is mainly influenced by considerations of economic liberalization, rather than considerations of social and labor rights of workers protection or establishing an optimal balance of interests of the parties to labor relations (Article 1 of the Labor Code of the Kyrgyz Republic). The potential for the effectiveness of coordinated interaction of social partners in the implementation of labor policy is largely not used, due to non-compliance with the requirements of labor legislation and international labor standards, or is still not fully used. Therefore, the problem of stable and effective participation of social partnership organizations in the development and implementation of legal policy in the world of labor is especially urgent. In terms of the considered problems of the policy of reforming the labor regulation sphere, it is necessary to note an urgent need to develop a unified state program for the development of the labor sphere, containing a system of strategic priorities, conceptual ideas, goals and measures that determine the prospects for improving labor legislation on the basis of intensifying the processes of its monitoring and practice of law enforcement in the Kyrgyz Republic.

The study was supported by a grant from the Russian Science Foundation (project No. 19-18-00517).

\section{References}

1. T.V. Tolbuzina, Eurasian Legal J. (2014). Accessed on: March 19, 2021. [Online]. Available: http://naukarus.com/o-dvuh-aspektah-reformy-v-trudovom-prave-rossii

2. V.A. Rudkovsky, Legal Concept, 1 (2014). Accessed on: March 19, 2021. [Online]. Available: https://cyberleninka.ru/article/n/pravovaya-politika-v-sistemeyuridicheskih-kategoriy

3. A.A. Dorskaya, Vestnik RGGU. Ser.: Ec., Management, Law, 1(144) (2015). Accessed on: March 19, 2021. [Online]. Available: https://cyberleninka.ru/article/n/tipologiyapravovyh-reform-1

4. Programma Pravitelstva Kyrgyzskoi Respubliki po razvitiyu chastnogo sektora v Kyrgyzskoi Respublike na 2015-2017 gody (podgotovlena ministerstvom ekonomiki Kyrgyzskoi Respubliki). (Prilozhenie 1) [Program of the Government of the Kyrgyz Republic for the Development of the Private Sector in the Kyrgyz Republic for 20152017 (prepared by the Ministry of Economy of the Kyrgyz Republic). (Appendix 1)] (2015). Accessed on: March 19, 2021. [Online]. Available: http://www.gov.kg/?p=51971\&lang=ru

5. Postanovlenie Pravitelstva Kyrgyzskoi Respubliki ot 12 yanvarya 2015 g. № 4 «O realizatsii proekta po regulyativnoi reforme «Sistemnyi analiz regulirovaniya» (realizatsiya etoi reformy koordinirovalas ministerstvom ekonomiki Kyrgyzskoi Respubliki) [Resolution of the Government of the Kyrgyz Republic dated January 12, 2015 No. 4 "On the implementation of the project on regulatory reform "System 
analysis of regulation" (the implementation of this reform was coordinated by the Ministry of Economy of the Kyrgyz Republic)]. Accessed on: March 19, 2021. [Online]. Available: http://cbd.minjust.gov.kg/act/view/ru-ru/97249?cl=ru-ru

6. S.Yu. Golovina, Labor Law in Rus. and Abroad 3, 3-8 (2020)

7. T.T. Miav, An employer's guide on managing your workplace during COVID-19: A guide for employers (International Labor Organization, Geneva, 2020)

8. Okhrana truda $v$ usloviyakh pandemii: nauchno-prakticheskoe posobie [Labor protection in a pandemic: a scientific and practical guide] (International Labor Organization, 2020)

9. ILO Convention No. 155 on Occupational Safety and Health and the Working Environment (1981). Accessed on: March 19, 2021. [Online]. Available:

https://www.ilo.org/wcmsp5/groups/public/---ed_norm/--normes/documents/normativeinstrument/wcms_c155_en.htm

10. N.L. Lyutov, E.S. Gerasimova, K.S. Ramankulov, Bul. Kyrgyz National Univ. J. Balasagyn., 60-74 (2018)

11. Proverochnyi list dlya obektov obshchestvennogo pitaniya, utv. sovmestnymi prikazami ministerstva ekonomiki Kyrgyzskoi Respubliki ot 21 iyunya 2016 g. №169 i Gosudarstvennoi inspektsii po ekologicheskoi i tekhnicheskoi bezopasnosti pri Pravitelstve Kyrgyzskoi Respubliki ot 31 maya 2016 g. №139 [Checklist for catering facilities, approved. joint orders of the Ministry of Economy of the Kyrgyz Republic dated June 21, 2016 No. 169 and the State Inspectorate for Environmental and Technical Safety under the Government of the Kyrgyz Republic dated May 31, 2016 No. 139]. Accessed on: March 19, 2021. [Online]. Available:

http://www.proverka.kg/media/uploads/files/gko/2_proverochnyiy_list_dlya_obyektov _torgovli_obschestvennogo_pitaniya_i_byitovogo_obslujivaniya.pdf

12. Konventsiya MOT № $81 \mathrm{ob}$ inspektsii truda v promyshlennosti i torgovle [ILO Convention No. 81 on Labor Inspection in Industry and Trade] (1947). Accessed on: March 19, 2021. [Online]. Available: https://www.ilo.org/wcmsp5/groups/public/--ed_norm/---normes/documents/normativeinstrument/wcms_c081_en.htm

13. Konventsiya №150 o regulirovanii voprosov truda: rol, funktsii i organizatsiya [Convention No. 150 on the regulation of labor issues: role, functions and organization] (1978). Accessed on: March 19, 2021. [Online]. Available: https://www.ilo.org/wcmsp5/groups/public/---ed_norm/--normes/documents/normativeinstrument/wcms_c150_en.htm

14. Konventsiya MOT №87 o svobode obedinenii i zashchite prava obedinyatsya $\mathrm{v}$ profsoyuzy [ILO Convention No. 87 on Freedom of Association and Protection of the Right to Organize in Trade Unions] (1948). Accessed on: March 19, 2021. [Online]. Available: https://www.ilo.org/wcmsp5/groups/public/---ed_norm/--normes/documents/normativeinstrument/wcms_c087_en.htm

15. J. Visser, Trade Union in the Balance (International Labor Organization, Geneva, 2019) 